\title{
The Functional Analysis of the Presidential Institution in Albania
}

\author{
Ilda Jeha \\ Tirana University, Albania
}

doi: 10.19044/esj.2017.v13n10p343 URL:http://dx.doi.org/10.19044/esj.2017.v13n10p343

\begin{abstract}
The Constitution of the Republic of Albania lays down the functional duties of the President of the Republic. Although the functions may have changed along the years, the President of the Republic has many important duties for the smooth operation of things in the country. Obviously, the President's Office is entrusted an unusual burdern that often puts it in a tight spot:on one side, quality of any decision issued is expected, but, on the other, the staff is quite limitted. These circumstances give particular importance to enhancing the efficiency of staff in this institution by optimising its organisational set-up; but, the approach imposed by the constitutional functions make it impossible for the President's advisors to deliver the proper quality.

On the contrary, all main and auxiliary functions need to be fulfilled by separate institutional units under the Secretary-General. Besides, the Assembly must immediately adopt an organic Law for the President, clearly stipulating how the President's Office must act in line with each constitutional function.

Such law would consolidate the President's Office position against any spontanous reaction and would avert any controversies on how it acts, as it would legaly align procedures to actions.
\end{abstract}

Keywords: Constitution, president, organisational structure, functional analysis, organic law

\section{Introduction}

The Constitution was the first obstacle to reforms launched after the political changes in Albania in $1991^{24}$. Designed for the previous system ${ }^{25}$, it contained many flaws and was not suitable to the market economy model: (i) as from the Preface, the Constitution referred to the Communist Party and

${ }^{24}$ Law 5506, dated 28.12,1976

${ }^{25}$ Law 5506, dated 28.12,1976 
the Party of Labour of Albania; it upheld State-owned property as the only form of ownership in the city and village, and proclaimed the class struggle and the fight against internal and foreign "enemies"; (ii) it sanctioned the social order: the dictatorship of proletariat, the one-party system: Party of Labour - the sole political force running the State and society, and construction of socialism on own means; (iii) it sanctioned also the economic order: socialist economy, socialist property (State-owned property and cooperative property) over the production means, and the personal property, i.e. only income from work and dwelling houses in village ${ }^{26}$; (iv) it sanctioned that the State leads and develops the whole economic and social life with a unique plan, State monopoly over external trade ${ }^{27}$ and any prices; (v) it prohibited granting of concessions and establishment of joint ventures with foreign companies, as well as foreign loans ${ }^{28}$; (vi) the position of the President of the Republic did not exist. The People's Assembly ${ }^{29}$ and its Presidium $^{30}$ were the supreme authorities of the State power; and (vii) it sanctioned the defendant's right to legal defence ${ }^{31}$.

Between the necessity for a new constitution and impossibility to continue the reforms under the democratic system and market economy, the option chosen was a provisional package of constitutional amendments ${ }^{32}$, aimed at laying down the basic principles of operation of the new democratic State: separation of powers and separation between State and private economy; it sanctioned political pluralism, allowed the diversity of property and free initiative, guaranteed the right to establish joint ventures with foreign companies and foreign loans. It was this package that introduced the position of the President of the Republic of Albania. Later on, the constitutional provisions were replaced by a new Constitution ${ }^{33}$ which, for the first time, elaborated the functions of the President.

The Constitution was amended several times along the years. The actual one was amended this year and adopted by the Assembly ${ }^{34}$. Amendments regulate issues about independence and functioning of the justice system, including the prosecution office and independent institutions, but also the constitutional position of the President of the Republic.

\footnotetext{
${ }^{26}$ Article 23.

${ }^{27}$ Article 27.

${ }^{28}$ Article 28.

${ }^{29}$ Article 66.

${ }^{30}$ Articles 75, 77, 78 and 79.

${ }^{31}$ Article 102. in the sense that the person is not entitled to a lawyer, but may defend himself

${ }^{32}$ Main constitutional provisions were adopted through Law no 7491, dated 29.4.1991.

${ }^{33} 1998$ Constitution was adopted by Constitutional Referendum on 22 November 1998, confirmed by Law no. 8417, dated 21.101998 and promulgated by Decree no. 2260, dated 28.11.1998 of the President of the Republic.

${ }^{34} \mathrm{Law}$
} 


\section{Constitutional functions of the President of the Republic}

The functions of the President of the Republic according to the 1998 Constitution amended through several laws, consider him as Head of State representing the unity of people who has the power to issue decrees . These decrees may be grouped in:

(i) Decisions on dates for meetings, referenda and elections. The President of the Republic determines the date of the first meeting of the newly elected Assembly ${ }^{35}$, requests that the Assembly meets in extraordinary session ${ }^{36}$, requests closed meetings of the Assembly ${ }^{37}$, dissembles the Assembly ${ }^{38}$ and determines the date of general and local elections or referenda ${ }^{39}$;

(ii) Promulgation or return of an adopted law for re-consideration to the Assembly; The President of the Republic promulgates each law adopted by the Assembly ${ }^{40}$ or returns it (only once) for reconsideration $^{41}$, as well as any law approved by referendum ${ }^{42}$;

(iii) Appointment of high officials; The President of the Republic appoints the Prime Minister (on the proposal of the party or coalition of parties that has the majority of seats in the Assembly) ${ }^{43}$, appoints and dismisses the Ministers (on the Prime Minister's proposal) ${ }^{44}$, the director of the National Intelligence Service (on the Prime Minister's proposal), the Chairman of the Academy of Sciences and Rectors of Universities (pursuant to law), proposes to the Assembly the election or dismissal of the Chairman of the High State Control ${ }^{45}$, appoints or withdraws plenipotentiary representatives of Albania to other States and International Organisations (on the Prime Minister's proposal) ${ }^{46}$;

(iv) Protocol functions; The President of the Republic accepts letters of credentials and withdrawal of diplomatic representatives of other States and International Organisations accredited in Albania ${ }^{47}$, whereas the Prime Minister ${ }^{48}$, Ministers ${ }^{49}$ and the judges of the

\footnotetext{
${ }^{35}$ Article 67 of Constitution of the Republic of Albania.

${ }^{36}$ Article 74 of Constitution of the Republic of Albania.

${ }^{37}$ Article 79 of Constitution of the Republic of Albania.

${ }^{38}$ Article 96 of Constitution of the Republic of Albania.

${ }^{39}$ Article 92 of Constitution of the Republic of Albania.

${ }^{40}$ Article 84 of Constitution of the Republic of Albania.

${ }^{41}$ Article 85 of Constitution of the Republic of Albania.

${ }^{42}$ Article 151 of Constitution of the Republic of Albania.

${ }^{43}$ Article 96 of Constitution of the Republic of Albania.

${ }^{44}$ Article 98 of Constitution of the Republic of Albania.

${ }^{45}$ Article 162 of Constitution of the Republic of Albania.

${ }^{46}$ Article 92 of Constitution of the Republic of Albania.

${ }^{47}$ Ibid.

${ }^{48}$ Article 99 of Constitution of the Republic of Albania.

${ }^{49}$ Ibid.
} 
Constitutional Court $^{50}$ are sworn in before him prior to taking on their duty;

(v) The President of the Republic is also Chairman of the High Council of Justice ${ }^{51}$ - He appoints 9 members of the Constitutional Court and its chairman (upon the consent of the Assembly) ${ }^{52}$, activates the Constitutional Court to initiate s proceeding ${ }^{53}$, appoints the members of the High Court (upon the consent of the Assembly) ${ }^{54}$, proposes the deputy chairman of the High Council of Justice ${ }^{55}$, who organises the meetings of the High Council of Justice, presides the meetings of the High Council of Justice ${ }^{56}$, appoints the Prosecutor General (upon the consent of the Assembly) ${ }^{57}$, discharges the Prosecutor General (upon the proposal of the Assembly) ${ }^{58}$, and appoints an discharges other prosecutors (upon the proposal of the Prosecutor General) ${ }^{59}$;

(vi) The President of the Republic is the Commander-in-Chief of the Armed Forces ${ }^{60}$ - The National Security Council is an advisory body to the President, and in times of peace, he exercises command of the Armed Forces through the Prime Minister and the Minister of Defence; $^{61}$ in times of war, he appoints and dismisses the Commander of the Armed Forces, upon the proposal of the Prime Minister; upon the proposal of the Minister of Defence, he appoints and dismisses the commanders of the army, navy and air force; ${ }^{62}$ he declares the state of war upon the request of the Council of Ministers, and imposes the state of general or partial mobilization or demobilisation $^{63}$;

(vii) Other functions - the President of the Republic requests opinions and information in writing from the directors of State institutions, concludes international agreements as by law ${ }^{64}$, addresses messages to the Assembly of Albania, exercises the right of pardon according to law, grants Albanian citizenship and permits that it be relinquished

\footnotetext{
${ }^{50}$ Article 129 of Constitution of the Republic of Albania.

${ }^{51}$ Article 147 of the Constitution of the Republic of Albania.

${ }^{52}$ Article 125 of the Constitution of the Republic of Albania.

${ }^{53}$ Article 134 of the Constitution of the Republic of Albania.

${ }^{54}$ Article 136 of the Constitution of the Republic of Albania.

${ }^{55}$ Article 147 of the Constitution of the Republic of Albania.

${ }^{56}$ Article 147 of the Constitution of the Republic of Albania.

${ }^{57}$ Article 149 of the Constitution of the Republic of Albania.

${ }^{58}$ Ibid.

${ }^{59}$ Ibid.

${ }^{60}$ Article 168 of the Constitution of the Republic of Albania.

${ }^{61}$ Article 169 of the Constitution of the Republic of Albania

${ }^{62}$ Ibid.

${ }^{63}$ Article 171 of the Constitution of the Republic of Albania.

${ }^{64}$ Ibid.
} 
according to law, grants decorations and titles of honour according to law, and grants the highest military ranks according to law ${ }^{65}$.

\section{Institution structures compared with functions}

But, how could Albanian presidents fulfil the above functions so far? In line with the purpose of the study, the focus of this analysis was the organisational structures of the President's institution, as an instrument that enables him to fulfil his functions. The period probed into is 2002-2006 during which Albania changed four Presidents ${ }^{66}$. This analysis leads to at least the following conclusions:

(i) Organisational structures have changed often: there are at least 10 Orders and Decisions for structural changes during the period. Many of them may involve simply a change of numbers, not units, and the philosophy for the construction of the institution remained the same. Otherwise, there is no other explanation for the issuance of two consecutive Decisions for changes within just four months; ${ }^{67}$

(ii) It is evident - during the period analysed - the concept of fulfilling the functions without administrative staff, but only through advisors. Each President of the Republic included in their Cabinet a number of advisors and assistants with professions and experience that he personally deemed reasonable for the delivery of the constitutional functions. So, the President of the Republic in 2002 had nine advisors: 2 diplomatic advisors, 1 legal advisor, 1 protocol advisor, 1 advisor for media and press, 1 political advisor, 1 military advisor, 1 security advisor and 1 economic advisor. Virtually the same organisational set-up was approved also in 2003, with minor changes related to the status of advisors and assistants to the President ${ }^{68}$. The same administrative philosophy was applied in at least 10 other Orders and Decisions issued by Presidents along the years. This is not a fair practice, because functions are left without expertise, while others are delivered at a low quality. The advisor cannot be responsible for a certain function; he can only advise the superior, by consenting or not to a decision/solution that somebody else is entitled to make;

(iii) The position of the Secretary General has been seen as just an administrative position, because the main functions of the institution never depended on him. In 2000, all structural units were subordinate to the Secretary General, including the Cabinet staff, expanding his span of management too much and senselessly, but this situation changed as of

65 Ibid.

${ }^{66}$ President Mejdani, President Mojsiu, President Topi and the actual President Nishani.

${ }^{67}$ Decision no. 279, dated 25.01.2013 and Decision no. 288, dated 14.05.2013.

${ }^{68}$ See Order no. 635, dated 27.02.2003 
2003. In the actual organisational set-up, ${ }^{69}$ there are 2 Directorates and 3 sectors subordinate to the Secretary General, of which, only the sector for external relations at the Directorate for External Relations and Communication may be somewhat related to the main functions of the institution. The other units (Directorates or Sectors) cover purely administrative auxiliary functions, or otherwise known as support functions (see Figure 1);

(iv) Overall, the President's institution has worked with incomplete structures. In the case of the actual President, while the fundamental functions of the position of the President of the Republic require a very solid legal unit, legal affairs are covered only by two advisors, because the legal affairs sector seems to be rather equivalent to the legal sector in Ministries. So, it handles the legal matters of the institution only. Management is simply an auxiliary function, and planning is an extremely reduced function compared to the other very important duties of this institution; both of them are at directorate level, i.e. Directorate for Planning and Management. This is a very significant administrative anomaly;

(v) Some constitutional functions of the President of the Republic are without expertise. In these conditions, the President takes decisions by himself, although he may seek advice from advisors. The institution lacks an administrative unit responsible for decisions related to dates of meetings, referenda or elections; none can institutionally check the figure of high officials proposed to obtain the appointment from the President of the Republic; the High Council of Justice is totally left at the hands of the deputy Chairman - who is a functionary - and now justice is sought to be reformed radically; the President's functions at times of war are never mentioned, on the premise that "we live in times of peace and there can be no war", while there is no direct designated responsibility for citizenships, decorations and high grades.

${ }^{69}$ Decision no. 332, dated 26.11.2015. 


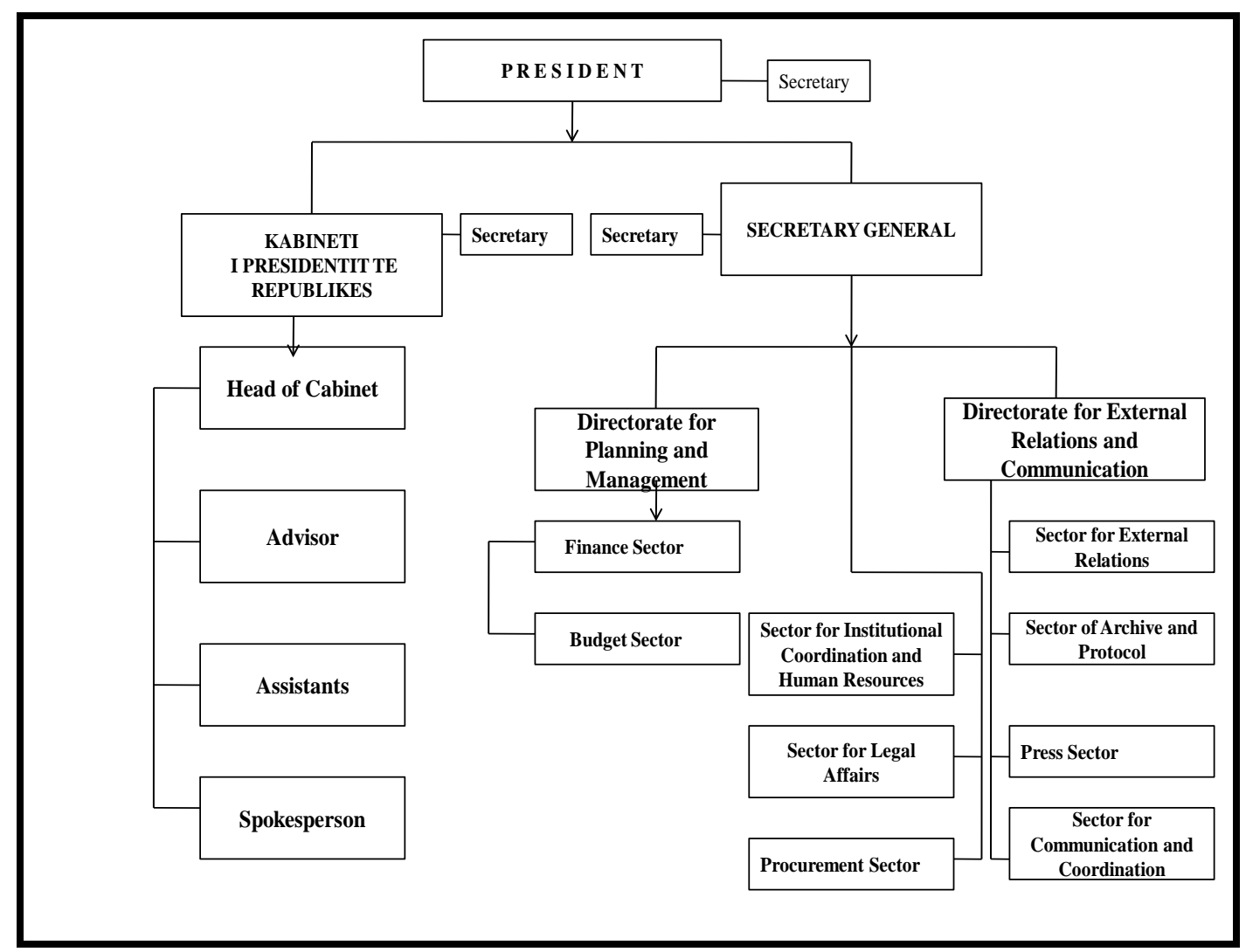

Fig. 1: The actual organisational set-up of the institution of the President of the Republic

\section{Proposal for a new structure}

Analysis of the organisational structures of the President's institution against his constitutional functions concludes that it needs a better set-up that leaves no function unconsidered.

Figure 2 gives such a model that can be easily tailored according to the staff available, or, as randomly said, the organics of the institution. 


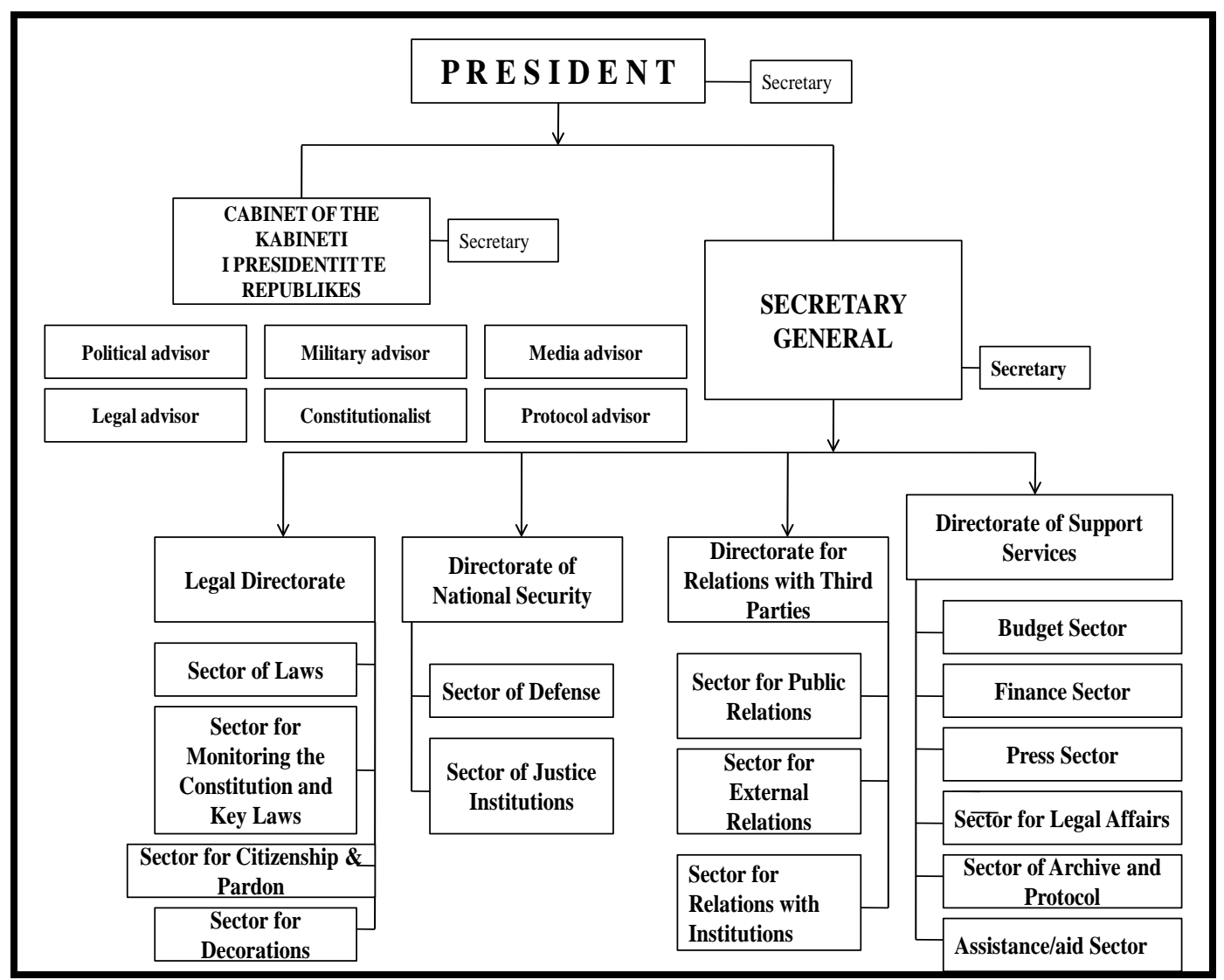

Fig. 2: Model of the Organisational Structure based on the functional analysis

This means that the number of permanent advisors may be reduced or increased by adding external advisors; the number of sectors within the Directorate of Support Services could be trimmed down, concentrating more than one function in each sector; and the name of "more technical directorates" could change, but the important thing is that each constitutional function or set of functions are assigned to an accountable person, so the President of the Republic is provided the proper instruments to take fair decisions.

\section{Conclusion and recommendations}

4.1 It is a wrong approach that the President of the Republic fulfils his constitutional functions through advisors that are part of his Cabinet, because it also hampers the quality of function delivery. The advisor must be considered solely as a consultative position and, at most, as an opponent of proposals by administrative units that offer solution options to any problem. The Cabinet could be made similar to that of the Prime Minister or Speaker of Assembly; 
4.2 The position of the Secretary General at the President's institution must not be simply an administrative second-hand position. He should cover all administrative units, regardless whether they exercise core or auxiliary functions. This ensures not only quality delivery of functions, but also the (actually missing) continuation of the technical staffs in this institution;

4.3 The President of the Republic has many important constitutional duties, although some of them are exercised upon the proposal of the Prime Minister or any of the Ministers. In these circumstances, it is indispensable to have an organic Law for the President's institution, clearly stipulating how this institution must act in line with each constitutional function. Such law would consolidate the President's Office position against any spontanous reaction and would avert any controversies on how it acts, as it would legaly align procedures to actions.

4.4 The President of the Republic has many other constitutional duties under certain laws. The analysis conducted under this study concluded that only a small part of these laws are already adopted, and this makes the President a target of the public and political parties any time he takes decisions not in line with certain interests. Therefore, it is recommended that the legal framework is completed as soon as possible, in accordance with the Constitution;

4.5 The impact of amendments to the Constitution and key laws must be measured regularly. For this, it is necessary to set up a monitoring unit at the President's institution that would report to the Assembly on the impact of legal changes annually. Such a report would also avoid $a$ priori considerations by political parties concerning constitutional changes made;

4.6 The President's institution must apply the engagement of external advisors. They must be the best in the fields selected by the President of the Republic; their position should be honorific and without remuneration, but their voice should be strongly heard and considered.

\section{References:}

1 Kushtetuta e Republikes Popullore Socialiste te Shqiperise, Tirane 1968.

$2 \quad$ Kushtetuta e Republikes se Shqiperise, Tirane 1998.

3 Vendime dhe Urdhra të Presidentëve të Republikës në lidhje me Strukturat Organizative të Institucionit të Presidentit, Tiranë 2002 2016.

4 F. Nicolas, The Span of Control and the Formulas of V. A. Graicunas, London, 2000. 
5 Silver R., Cabiri Y., PAR in Albania: Ministry of Finances, WB sponsored, Tirana, June 2005.

6 Silver R., etc., PAR in Albania: Guidelines for restructuring central institutions, based in the Management Span analyses, WB sponsored, Tirana June 2009.11.

7 Jeha I., Cabiri Y., Analizë krahasuese e hapësirës menaxhuese në institucionet qendrore, The Heritage, October 2016.

8 Bohte J., Meier J. K., Structure and the Performance of Public Organizations: Task Difficulty and Span of Control, Oakland University, Rochester, MI 48309, September 2001.

9 Van Fleet D., Bedeian A., A History of the Span of Management, Texas A\&M University, Academy of Management Revieë, July 1997. 